\title{
KANDUNGAN FENOLAT DAN AKTIVITAS ANTIOKSIDAN UBI BANGGAI ( Dioscorea ) DARI BERBAGAI VARIETAS
}

\author{
Oleh : \\ Joice Noviana Pelima
}

\begin{abstract}
The aims of this study were to determination three varieties of banggai yam of phenolic content and activity antioxidant. Research methods use the complete random methods to applied varieties of banggai yam treatment were purple yam, yellow yam and white yam to repeatedly 5 times and due to get 15 experiment units. The influence of the ratio of ethanol varieties banggai yam flour and extraction time treatment to producted extract phenolic content and influence varieties of banggai yam phenolic content and activity antioxidant applied to achieve this aims. The results shown that highest phenolic content (2,63\%) for white banggai yam, 2,44\% for purple banggai yam and 1,90\% for yellow banggai yam at ratio 15:1 based volume/weight $(v / w)$ and time extraction at 2 hours. The highest antioxidant activity ethanol extract (74,87\%) finded to white banggai yam extract and lowest antioxidant activity $(37,19 \%)$ finded to yellow banggai yam. Antioxidant activity have relations with phenolic content. Antioxidant activity of 200 ppm BHT as positively control no significant different with activity antioxidant white banggai yam ekstract
\end{abstract}

Key word: phenolic content, activity antioxidant, ethanol extract, varieties of banggai yam

\begin{abstract}
Abstrak
Penelitian ini bertujuan untuk menentukan kandungan fenolat dan aktivitas antioksidan pada tiga varietas ubi banggai. Rancangan penelitian menggunakan Rancangan Acak Lengkap (RAL) dengan perlakuan varietas ubi banggai yang terdiri dari 3 varietas ubi banggai yaitu ubi ungu, ubi kuning, ubi putih dan diulang 5 kali sehingga diperoleh 15 unit percobaan. Pencapaian tujuan dilakukan dengan menerapkan perlakuan pengaruh ratio pelarut etanol terhadap tepung ubi banggai dan pengaruh waktu ekstraksi terhadap kadar fenolat ekstrak yang dihasilkan, serta pengaruh jenis ubi banggai terhadap kadar fenolat dan aktivitas antioksidan ekstrak etanol. Hasil yang diperoleh menunjukkan kadar fenolat tertinggi $(2,63 \%)$ untuk ubi banggai putih $2,44 \%$ untuk ubi banggai ungu dan $1,90 \%$ untuk ubi banggai kuning pada ratio $15: 1$ atas dasar v/b dan pada waktu ekstraksi 2 jam. Aktivitas antioksidan ekstrak etanol tertinggi $(74,87 \%)$ ditemukan pada ekstrak ubi banggai putih dan aktivitas antioksidan terendah $(37,19 \%)$ pada ekstrak etanol ubi banggai kuning. Aktivitas antioksidan sejalan dengan kandungan fenolat. Aktivitas antioksidan BHT 200 ppm sebagai kontrol positif tidak berbeda dengan aktivitas antioksidan ekstrak ubi banggai putih
\end{abstract}

Kata kunci :Kandungan fenolat, aktivitas antioksidan, ekstrak etanol, varietas ubi banggai

\section{LATAR BELAKANG}

Makanan dan kesehatan adalah dua hal penting yang terkait erat satu sama lain. Perkembangan dan kemajuan ilmu pengetahuan dan teknologi telah menimbulkan dampak positif maupun negatif dibidang kesehatan. Salah satu dampak negatifnya adalah timbul berbagai jenis penyakit kronis akibat pola makan seperti kanker, jantung koroner, hipertensi yang mengarah ke stroke, penuaan dini dan terganggunya sistem kekebalan tubuh (Sabili, 2007). Hasil penelitian dari berbagai peneliti menyatakan bahwa timbulnya penyakit kronis 
tersebut dipicu oleh adanya radikal bebas. Aktivitas molekul radikal bebas dapat menimbulkan stress oksidatif yang menyebabkan berbagai penyakit. Stress oksidatif sendiri adalah keadaaan tidak seimbangnya jumlah oksidan dan prooksidan dalam tubuh (Sabili, 2007). Senyawa kimia yang mampu menghambat penuaan dan mengatasi berbagai penyakit kronis yang diakibatkan oleh radikal bebas adalah senyawa kimia yang disebut antioksidan.

Antioksidan yang dikenal saat ini terdiri atas antioksidan sintesis dan antioksidan alami. Menurut Barus ( 2009 ) penggunaan antioksidan sintetis tidak direkomendasikan oleh Departemen Kesehatan melalui Badan Pengawas Obat dan Makanan (BPOM) karena diduga dapat menimbulkan penyakit kanker (carcinogen agent) (Hernani dan Raharjo, 2005 dalam Barus, 2009). Oleh karena itu perlu dicari alternatif lain yaitu antioksidan alami. Menurut Sabili (2007) yang dimaksud antioksidan alami adalah antioksidan hasil ekstraksi bahan alami tumbuhan maupun mikroba.

Tanaman ubi banggai termasuk family Dioscoreaceae merupakan tumbuhan merambat dan memiliki umbi akar yang kadang berukuran sangat besar (Wikipedia, 2006 ). Rahmatu, Ramadhanil dan Sangaji (2001) menemukan 11 spesies tumbuhan yang tergolong dalam famili Dioscoreaceae, yaitu: Babanal (Dioscorea warburgiana Uline), Ondot (Dioscorea hispida Dennst.), Siloto (Dioscorea cf. deltoidea Wall.), Bakutu (Dioscorea glabra Roxb.), Baku makuloloang (Dioscorea bulbifera var. celebica Burkill), Baku pusus (Dioscorea cf. alata), Dioscorea keduensis Burkill, Dioscorea numularia, Ndolungun (Dioscorea esculenta [Lour.] Burck.), Baku butun (Dioscorea alata L.). Salah satu ciri yang membedakan varietas ubi banggai adalah warna umbinya. Umbi yang berwarna menandakan bahwa ubi banggai mengandung komponen kimia yang berfungsi sebagai antioksidan alami.

Ubi banggai (Dioscorea) termasuk salah satu marga tanaman yang tidak bisa dipisahkan dengan kehidupan masyarakat Banggai Kepulauan (Bangkep). Hal tersebut disebabkan karena ubi banggai merupakan salah satu makanan pokok masyarakat Bangkep, yang banyak ditemukan di Kecamatan Banggai dan Lainag. Dengan hasil 8.933,9 ton ubi banggai memberikan kontribusi yang signifikan dalam peningkatan pendapatan daerah (Sarjadi, 2009). Masyarakat setempat mengolah ubi ini menjadi kolak, kripik, kue atau di rebus biasa layaknya makanan utama. Pola makan dengan mengkonsumsi ubi sebagai menu utama pada dasarnya adalah pola makan yang sehat dan patut untuk di pertahankan serta dikembangkan.

Warna ubi banggai yang teridentifikasi terdiri dari tiga golongan besar yaitu warna ungu, kuning dan putih. Banyak kultivarnya yang memiliki umbi berwarna ungu sehingga dalam bahasa Inggris dikenal sebagai purple yam (Wikipedia Indonesia, 2006 ). Umbi 
berwarna ungu disebabkan karena adanya pigmen antosianin, sedangkan umbi yang berwarna kuning disebabkan oleh adanya kandungan betakaroten (Risniati, 2009). Kandungan beta karoten dan antosianin serta tokoferol dan senyawa - senyawa fenolat berfungsi sebagai antioksidan (Hidayat, 2008; Retnati, 2009).

Sebagai perbandingan ubi jalar kaya akan serat, mineral, vitamin dan antioksidan seperti asam fenolat, antosianin, tokoferol dan beta karoten ( Hidayat, 2008). Kandungan fenolat pada ubi jalar sekitar $0,14-0,51 \mathrm{mg} / \mathrm{g}$ berat segar. Kandungan antosianin pada ubi jalar ungu lebih tinggi daripada ubi yang berwarna putih, kuning, dan jingga (Suardi, 2005 dalam Retnati, 2009). Hal ini diperkuat oleh hasil penelitian Suprapta (2003) dalam Retniati (2009) bahwa kandungan antosianin dalam ubi jalar putih adalah 0,06 mg/100g, ubi jalar kuning 4,56 mg/100g, dan ubi jalar ungu 110,51 mg/100g. Ubi jalar ungu mengandung $0,4-$ 0,6 $\mathrm{mg}$ antosianin/g berat segar (Hidayat, 2008).

Berdasarkan hal itu, terdapat indikasi ubi banggai mengandung senyawa fenolat, karotenoid dan antosianin yang berperan sebagai antioksidan alami.

\section{METODE PENELITIAN}

Jenis penelitian ini adalah penelitian eksperimen yang dilaksanakan pada bulan Pebruari sampai bulan Juni 2012 di Laboratorium Penelitian Kimia Jurusan Kimia, Fakultas Matematika dan Ilmu Pengetahuan Alam Universitas Tadulako Palu. Bahan dasar yang digunakan adalah ubi banggai yang diperoleh dari petani Banggai Kepulauan, terdiri atas 3 varietas, ubi banggai berwarna ungu, putih dan kuning. Bahan lain sebagai bahan pengekstrak dan bahan kimia untuk analisis mencangkup etanol teknis, fenol, $\mathrm{NH}_{4} \mathrm{OH} 0,5 \mathrm{~N}$, buffer fosfat ( $\mathrm{pH}=12$ ), indikator Metil Orange (MO), asam fosfat, minyak kedelai, tween 20, ammonium tiosianat $30 \%$, ferroklorida $0,02 \mathrm{M}, \mathrm{HCl} 3,5 \%$, aquades, alumunium foil dan kertas saring. Peralatan yang digunakan terdiri atas : blender, ayakan 60 mesh, talang alumunium, neraca analitik, mesin kocok, penangas air, rotary evaporator, lemari pendingin, Spektrofotometer UV-VIS, kuvet, corong buchner,labu ukur, gelas ukur, erlenmeyer dan alat - alat gelas yang umum digunakan dalam laboratorium Kimia.

Penelitian ini dirancang dengan menggunakan Rancangan Acak Lengkap (RAL) dengan perlakuan varietas ubi banggai yaitu varietas Dioscorea bulbifera var celebica Burkill dengan umbi berwarna ungu, varietas Dioscorea sp dengan umbi berwarna kuning dan varietas Dioscorea of alata dengan umbi berwarna putih. Masing - masing perlakuan diulang 5 kali sehingga diperoleh 15 unit percobaan

Penelitian ini dilaksanakan dengan 2 tahap yaitu : pembuatan tepung ubi banggai selanjutnya ekstraksi dan analisis kandungan fenolat ekstrak etanol ubi banggai. 


\section{Pembuatan Tepung Ubi Banggai}

Ubi banggai ( 3 varietas ) yang di peroleh dari Petani ubi banggai di daerah Banggai Kepulauan dicuci sampai bersih dan direndam dalam air mendidih selama 7 menit, kemudian ditiriskan dan diiris tipis. Irisan ubi banggai selanjutnya dikeringkan di bawah sinar matahari hingga kering, kemudian dibuat menjadi tepung menggunakan blender. Tepung ubi banggai yang dihasilkan selanjutnya disimpan dalam wadah plastik sebelum digunakan dalam penelitian selanjutnya.

\section{Ekstraksi dan Analisis Kandungan Fenolat Ekstrak Etanol Ubi Banggai}

Ekstraksi dan analisis kandungan fenolat tepung ubi banggai dari 3 varietas dilakukan bertahap sebagai berikut :

\section{Ekstraksi Ubi Banggai}

Tepung ubi banggai dari tiga varietas ditimbang dengan berat tertentu, kemudian dimasukkan ke dalam erlenmeyer dan ditambahkan etanol. Rasio etanol terhadap tepung ubi yang diterapkan terdiri atas rasio $5: 1$ (A), $7: 1$ (B), $9: 1$ (C), $11: 1$ (D), $13: 1$ (E), $15: 1$ (F), $17 ; 1$ (G), atas dasar volume/berat (v/b). Setiap perlakuan diulang lima kali sehingga terdapat tiga puluh lima unit percobaan. Ekstraksi berlangsung diatas mesin kocok agitasi 200 rpm selama 2 jam. Campuran selanjutnya disaring untuk mendapatkan ekstrak etanol tepung ubi banggai. Ekstrak yang diperoleh dipekatkan secara vakum menggunakan rotary evaporator. Parameter yang diamati adalah kadar fenolat tepung ubi banggai menggunakan metode spektrofotometri. Rasio etanol terhadap tepung ubi yang menghasilkan kadar fenolat tertinggi dinyatakan sebagai rasio etanol terhadap tepung ubi terseleksi dan digunakan pada tahap penentuan waktu ekstraksi.

Waktu esktraksi yang diterapkan terdiri atas 1 jam (A), 2 jam (B), 3 jam (C), 4 jam (D) dan 5 jam (E). Setiap perlakuan diulang lima kali sehingga terdapat dua puluh lima unit percobaan. Parameter yang diamati adalah kadar fenolat tepung ubi banggai menggunakan metode spektrofotometri. Waktu ekstraksi yang menghasilkan kadar fenolat tertinggi dari 3 varietas ubi banggai digunakan untuk uji aktivitas antioksidan.

\section{Uji Aktivitas Antioksidan Ekstrak Etanol Ubi Banggai (Pujimulyani dkk, 2006)}

Ekstrak yang dihasilkan ditepatkan volumenya masing-masing $50 \mathrm{~mL}$. Kemudian dibuat campuran minyak kedelai dengan cara mencampurkan minyak kedelai 0,2840 g, 0,2840 g tween 20 dan $50 \mathrm{ml}$ buffer posfat $\mathrm{pH}$ 7,0 dan dihomogenisasi. Setelah itu di pipet $0,8 \mathrm{~mL}$ dari masing-masing konsentrasi ekstrak ubi banggai dan ditambahkan 1,0 mL campuran minyak kedelai. Campuran ekstrak dan campuran minyak kedelai diinkubasi selama 24 jam pada suhu $50^{\circ} \mathrm{C}$. Selanjutnya, campuran yang telah diinkubasi, ditambahkan 
$10 \mathrm{~mL}$ etanol 75\%, 0,2 $\mathrm{mL}$ ammonium tiosianat $(30 \%)$ dan $0,2 \mathrm{~mL}$ ferroklorida $(0,02 \mathrm{M}$ dalam $\mathrm{HCl} 3,5 \%$ ), didiamkan selama 30 menit, dan diukur absorbansinya dengan spektrofotometer pada panjang gelombang $510 \mathrm{~nm}$. Setelah itu, dibuat blanko yaitu campuran tanpa menggunakan ekstraksi ubi banggai yang terdiri dari 1,0 mL campuran minyak kedelai ditambahkan $10 \mathrm{~mL}$ etanol 75\%, 0,2 mL ammonium tiosianat (30\%) dan 0,2 $\mathrm{mL}$ ferroklorida $(0,02 \mathrm{M}$ dalam $\mathrm{HCl} 3,5 \%)$ dan diukur absorbansinya dengan spektrofotometer pada panjang gelombang $510 \mathrm{~nm}$. Sebagai pembanding digunakan antioksidan sintetik Butylated Hidroksi Toluen (BHT) 200 ppm, dengan prosedur kerja yang sama dengan penggunaan ekstrak ubi banggai.

Aktivitas antioksidan ditentukan menggunakan persamaan berikut :

Aktivitas antioksidan $(\%)=1-\frac{\text { Asampel }}{\text { A blanko }} \times 100 \%$

\section{Teknik Pengumpulan Data}

\section{Penentuan Kadar Fenolat Ubi Banggai ( SNI dalam Leman, 2009 )}

\section{a. Pembuatan kurva baku}

Fenol murni ditimbang sebanyak $1 \mathrm{~g}$ kemudian dimasukkan ke dalam gelas kimia dan ditambahkan aquades sekitar $100 \mathrm{~mL}$, selanjutnya diaduk hingga semua fenol larut. Larutan fenol dipindahkan secara kuantitatif ke dalam labu ukur 1 liter dan ditepatkan volumenya dengan aquades. Larutan fenol diambil dengan pipet volum, kemudian dimasukkan ke dalam labu ukur $50 \mathrm{~mL}$ dan ditepatkan volumenya dengan aquades. Larutan ini diencerkan untuk mendapatkan larutan standar fenol dengan konsentrasi 5 ppm, 10 ppm, 15 ppm, 20 ppm dan 25 ppm, dalam labu ukur $50 \mathrm{~mL}$. Setiap larutan dipindahkan ke dalam erlenmeyer $100 \mathrm{~mL}$ kemudian dipanaskan dalam penangas air selama 5 menit, lalu ditambahkan 1-2 tetes indikator metil orange (MO) sampai terbentuk warna kuning. Larutan selanjutnya ditambahkan 2-3 tetes asam fosfat 1 : 9 sampai terbentuk warna merah jingga. Larutan didinginkan kemudian ditambahkan 1,2 $\mathrm{mL}^{\mathrm{NH}} \mathrm{NH}_{4} \mathrm{OH} 0,5 \mathrm{~N}$, kemudian diatur $\mathrm{pH}$ larutan hingga 7,9 $\pm 0,1$ dengan buffer fosfat ( $\mathrm{pH}=12$ ). Masing - masing larutan diukur serapannya pada panjang gelombang maksimum $(460 \mathrm{~nm})$ berdasarkan hasil pengukuran spektrum serapan larutan standar fenol $10 \mathrm{ppm}$. Hasil pengukuran serapan diplotkan dalam kurva hubungan antara absorban terhadap konsetrasi fenol untuk menghasilkan kurva baku.

\section{b. Analisis Sampel}

Ekstrak tepung ubi yang diperoleh dari tahap sebelumnya, kemudian dimasukkan ke dalam erlenmeyer $100 \mathrm{~mL}$ kemudian dipanaskan dalam penangas air selama 5 menit, lalu ditambahkan 1-2 tetes indikator metil orange (MO) sampai terbentuk warna kuning. Larutan 
selanjutnya ditambahkan 2-3 tetes asam fosfat $1: 9$ sampai terbentuk warna merah jingga. Larutan didinginkan kemudian ditambahkan $1,2 \mathrm{ml} \mathrm{NH}_{4} \mathrm{OH} 0,5 \mathrm{~N}$, kemudian diatur $\mathrm{pH}$ larutan hingga 7,9 $\pm 0,1$ dengan buffer fosfat $(\mathrm{pH}=12)$. Sampel kemudian diukur pada panjang gelombang maksimum $(460 \mathrm{~nm})$. Total fenolat sampel ditentukan dengan rumus :

Kadar fenolat $(\%)=\underline{X(\mathrm{mg} / 1000 \mathrm{~mL}) \times \text { vol. Sampel }(\mathrm{ml})} \times 100 \%$

Bobot sampel (mg)

Keterangan: $\mathrm{X}=$ Konsentrasi fenolat $(\mathrm{mg} / 1000 \mathrm{ml})$

\section{Uji Aktivitas Antioksidan}

Untuk uji aktivitas antioksidan ditentukan menggunakan rumus :

Aktivitas antioksidan $(\%)=1-\frac{\text { A sampel }}{\text { A blanko }} \times 100 \%$

\section{Teknik Analisis Data}

Data yang diperoleh dalam penelitian akan dianalisis dengan varian/sidik ragam, apabila terdapat pengaruh antar perlakuan akan dilanjutkan dengan uji BNJ pada taraf signifikan $\alpha=5 \%$.

\section{HASIL DAN PEMBAHASAN}

\section{Kurva Baku Fenol}

Kadar fenolat total dalam ekstrak ubi banggai dari berbagai varietas dilakukan menggunakan metode spektrofotometri. Metode tersebut diawali dari pembuatan kurva baku menggunakan senyawa fenol murni. Serapan maksimum larutan baku fenol murni ditemukan pada panjang gelombang $460 \mathrm{~nm}$. Hasil pengukuran serapan larutan standart fenol antara konsentrasi 5 ppm dan 25 ppm dengan selang konsentrasi 5 ppm disajikan pada Lampiran 3 Gambar 4.1. Hubungan antara absorbans (serapan) terhadap konsetrasi fenol mengikuti kurva linier dengan persamaan $\mathrm{Y}=0,017 \mathrm{x}+0,111$, dan koefisien regresi $\left(\mathrm{R}^{2}\right)$ mendekati 1 yakni 0,999 (Gambar 4.1). Hal tersebut memberikan indikasi linieritas antara serapan terhadap konsentrasi cukup tinggi (Miller, 1993; Ibrahim, 1997). 


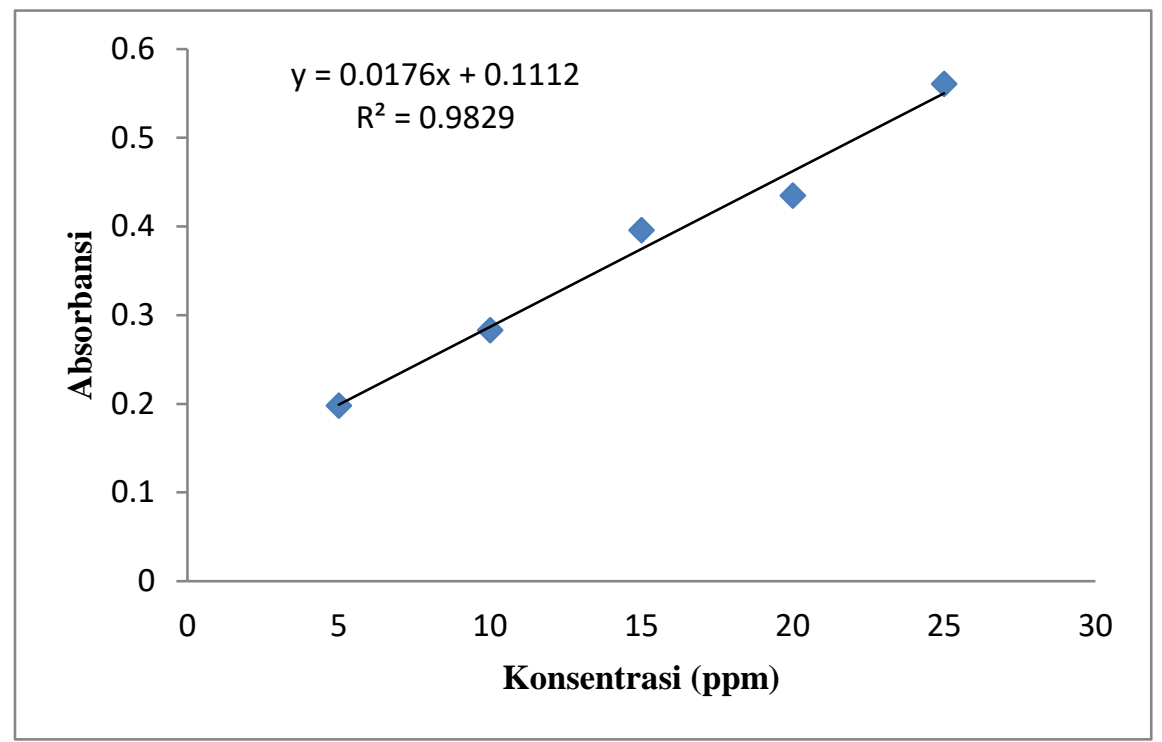

Gambar 4.1. Kurva baku fenol pada panjang gelombang $460 \mathrm{~nm}$

\section{Kadar Fenolat Total Pada Berbagai Ratio Tepung Ubi Banggai/Pengekstrak etanol}

Salah satu faktor yang berpengaruh terhadap rendemen ekstrak suatu proses ekstraksi adalah konsentrasi pengekstrak relatif terhadap jumlah yang diekstrak atau ratio antara pengekstrak terhadap bahan yang diekstrak. Berdasarkan hal itu dilakukan ekstraksi senyawa fenolat ubi banggai dengan pengekstrak etanol pada berbagai ratio pengekstrak etanol terhadap tepung ubi banggai. Kadar fenolat total tertinggi untuk ketiga varietas ubi banggai (ubi ungu, ubi kuning dan ubi putih) ditemukan pada ratio $15: 1$ atas dasar volume/berat (v/b), akan tetapi kadar fenolat total berbeda antar varietas ubi banggai (Gambar 4.2 Tabel Lampiran 6). Ubi banggai putih menghasilkan ekstrak etanol dengan kadar fenolat tertinggi 2,63\% kemudian ubi banggai ungu dengan kadar fenolat 2,44\% dan terakhir sebagai kadar fenolat terendah terdapat pada ubi banggai kuning sebesar $1,90 \%$

Hasil penelitian Fitrya $d k k$ (2010) menyatakan bahwa dari fraksi etil asetat kulit batang tumbuhan Gandaria (Воиеa macrophylla Griff) berhasil diisolasi senyawa yang berupa kristal berwarna putih sebanyak $10 \mathrm{mg}$. Berdasarkan analisis spektroskopi dan uji fitokimia dengan pereaksi senyawa warna $\mathrm{FeCl}_{3}$ diduga senyawa tersebut merupakan senyawa golongan fenolat yang tersubstitusi oleh gugus alifatik dan gugus karbonil. Sedangkan Wijono (2004) menemukan bahwa dari ekstrak etanol 95\% simplisia daun katu (Sauropus androgynus (L.) Merr. ) telah diisolasi senyawa - senyawa asam fenolat yang diidentifikasi sebagai asam p-hidroksibenzaoat, asam ferulat, asam vanilat dan asam kafeat. Hasil analisis kuantitatif menunjukkan bahwa asam p-hidroksibenzoat mempunyai presentase yang tertinggi diantara keempat jenis asam fenolat yang telah diidentifikasi. 
Perbedaan kadar fenolat antar varietas ubi banggai diduga disebabkan oleh perbedaan varietas yang berkaitan dengan komposisi kimia umbi karena faktor genetik seperti species. Hal ini didukung oleh Farah dan Donanngelo (2006) yang menyatakan bahwa varietas sangat menentukan komposisi kimiawi tanaman. Umbi banggai kuning diduga mengandung karotenoid yang relatif tinggi dibandingkan dengan ubi banggai lainnya. Sebagai perbandingan umbi kuning pada ubi jalar (Ipomoea batatas L.) mengandung betakarotin antara 245,30 ug - 533,80 ug (Limbongan dan Albert, 2007). Dengan kandungan yang tinggi tersebut, maka kandungan fenolatnya kemungkinan menurun. Demikian pula ubi banggai ungu mengandung flavonoid yang relatif lebih tinggi dibandingkan dengan ubi banggai kuning. Kelompok terbesar dari senyawa fenolik adalah flavonoid, yang merupakan senyawa yang secara umum dapat ditemukan pada semua jenis tumbuhan dan antosianin yang terdapat pada umbi berwarna ungu termasuk senyawa flavonoid (Herdiansyah $d k k$, 2011). Dengan kandungan flavonoid yang tinggi maka kadar fenolatnya relatif lebih tinggi dibandingkan dengan ubi banggai kuning akan tetapi relatif lebih rendah dibandingkan dengan ubi banggai putih.



Gambar 4.2 Kurva hubungan kadar fenolat total terhadap rasio etanol terhadap tepung ubi

Pola perubahan kadar fenolat pada berbagai ratio untuk semua varietas ubi banggai mengikuti garis kurva parabola yang menunjukkan adanya daerah ratio yang kadar fenolatnya meningkat dan kadar fenolatnya menurun (Gambar 4.2). Pengekstrak etanol pada ratio $5: 1$, $7: 1,9: 1$ dan $11: 1$ belum cukup optimal berpenetrasi dalam tepung ubi banggai akibatnya kadar fenolat yang dilarutkan juga belum optimal. Pada ratio $13: 1$ mulai terjadi peningkatan 
kadar fenolat yang terlarut tetapi belum mencapai kadar yang optimum. Kadar fenolat total tertinggi untuk semua jenis ubi banggai ditemukan pada ratio etanol 15:1 karena pada ratio ini tepung ubi banggai mencapai kadar fenolat yang optimum. Pola ini ditemukan juga oleh Noviyanty (2011) dan Fitrya $d k k$ (2010).

Ratio etanol/tepung ubi banggai berpengaruh sangat nyata terhadap kadar fenolat (Tabel Lampiran 7). Hasil analisis lanjut dengan UJI BNJ taraf 5\% menunjukkan ratio ethanol/ubi banggai 15:1 (v/b) berbeda dengan ratio etanol/ubi banggai yang lain untuk semua jenis ubi banggai (Tabel Lampiran 8).

\section{Kadar Fenolat Total Pada Berbagai Waktu Ekstraksi}

Faktor lain yang juga turut berpengaruh terhadap kadar fenolat hasil ekstraksi adalah waktu ekstraksi. Untuk mengetahui waktu ekstraksi yang menghasilkan ekstrak dengan kadar fenolat tinggi diterapkan perlakuan pengaruh waktu ekstraksi terhadap kadar fenolat. Kadar fenolat tertinggi untuk semua jenis ubi banggai ditemukan pada waktu ekstraksi 2 jam (Gambar 4.3 Tabel Lampiran9). Ubi banggai puth kadar fenolat tertinggi (2,62\%) ditemukan pada waktu ekstraksi 2 jam, dan kadar fenolat terendah (1,55\%) terdapat pada waktu ekstraksi 1 jam. Ubi banggai ungu kadar fenolat tertinggi (2,39\%) ditemukan pada penggunaan waktu ekstrak 2 jam, dan kadar fenolat terendah $(1,15 \%)$ terdapat pada waktu ekstraksi 5 jam. Ubi banggai kuning kadar fenolat terrtinggi $(1,90 \%)$ ditemukan pada waktu ekstraksi 2 jam, dan kadar fenolat terendah $(1,13 \%)$ terdapat pada waktu ekstraksi 5 jam.

Kadar fenolat terendah ubi banggai putih pada waktu ekstraksi 1 jam diduga karena ubi banggai putih memerlukan waktu ekstraksi lebih lama untuk melarutkan senyawa fenolat yang dikandungnya. Sedangkan kadar fenolat terendah ubi banggai ungu dan ubi banggai kuning diduga disebabkan waktu ekstraksi lebih dari 2 jam mengakibatkan senyawa fenolat mengalami dekomposisi sebagaimana dikemukakan Palupi $d k k$ (2007) bahwa senyawa polifenol seperti fenolat dan flavonoiddan tanin akan mudah teroksidasi dengan adanya oksigen membentuk senyawa radikal orto-kuinon. 


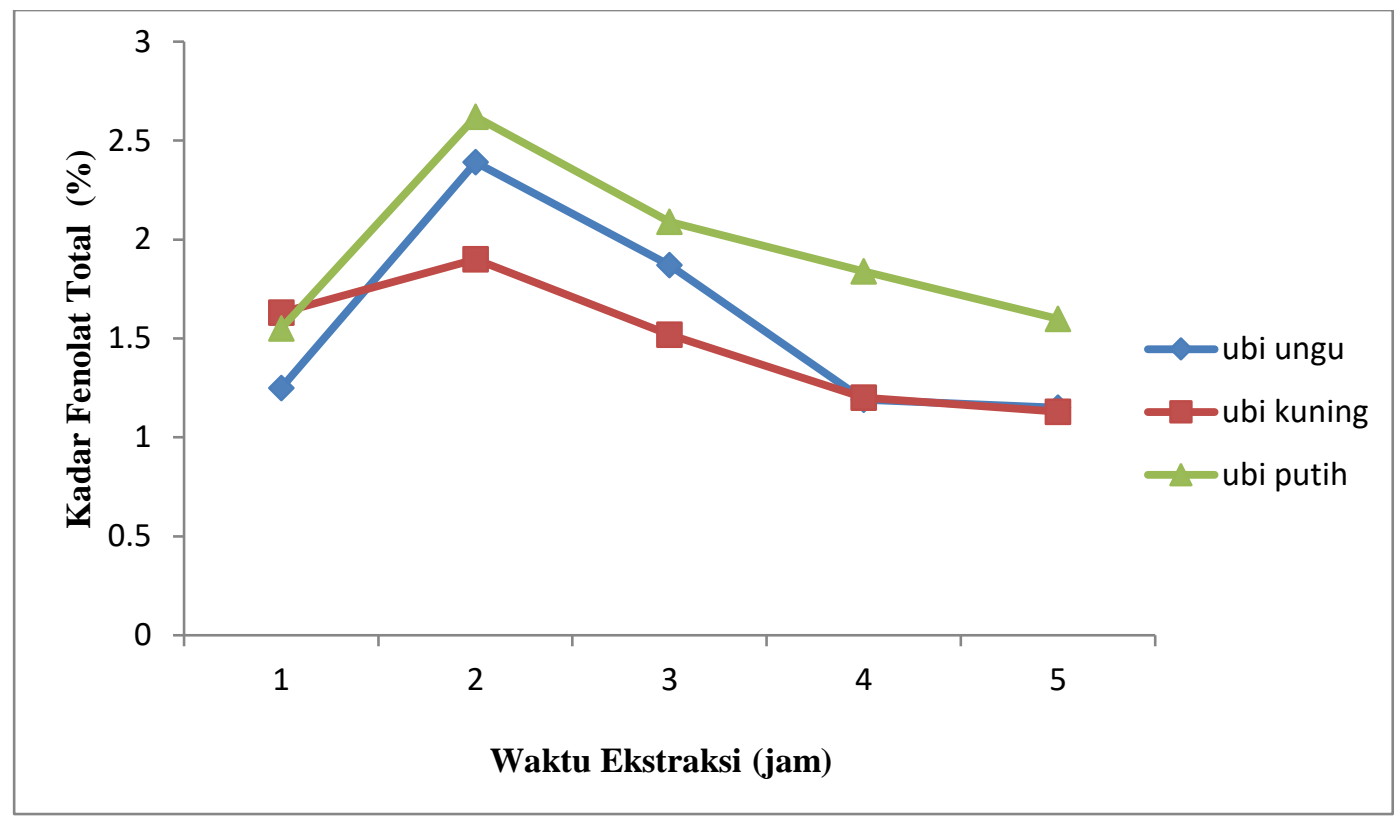

\section{Gambar 4.3 Kurva hubungan kadar fenolat total terhadap waktu esktraksi}

Perubahan kadar fenolat total terhadap waktu reaksi mengikuti pula perubahan garis kurva parabola dimana waktu ekstraksi optimumnya terjadi pada waktu reaksi 2 jam (Gambar 4.3). Pola perubahan kadar fenolat total yang juga ditemukan oleh Septiani (2011). Pola perubahan kadar fenolat total terhadap waktu ekstraksi menunjukkan bahwa makin lama ekstraksi maka fenolat yang diperoleh makin banyak dan mencapai titik optimumnya pada waktu ekstraksi 2 jam dimana proses ekstraksi fenolat mencapai titik optimumnya dan selanjutnya mulai menurun sampai ekstrak jenuh terhadap etanol.

Pola perubahan kadar fenolat terhadap waktu reaksi yang mengikuti kurva parabola memberikan petunjuk senyawa fenolat mudah teroksidasi selama proses ekstraksi. Fenolat dalam ketiga varietas umbi telah mengalami oksidasi setelah waktu ekstraksi 2 jam. Faktor penyebab kerusakan fenolat selama ekstraksi diduga disebabkan oleh faktor cahaya yang mengakibatkan senyawa fenol mengalami oksidasi oleh enzim tertentu sehingga terjadi dekomposisi fenolat. Disamping itu etanol sebagai pengekstrak ikut menguap sehingga mempengaruhi kadar fenolat ekstrak yang dihasilkan.

Analisis ragam menunjukkan waktu ekstraksi berpengaruh sangat nyata terhadap kadar fenolat (Tabel Lampiran 10). Analisis lanjut dengan Uji BNJ taraf 5\% menunjukkan kadar fenolat berbeda antar waktu ekstraksi (Tabel Lampiran 11). Hal ini memperkuat dugaan bahwa pola perubahan kadar fenolat terhadap waktu ekstraksi mengikuti kurva parabola. 


\section{Aktivitas Antioksidan Ekstrak Etanol Ubi Banggai}

Senyawa fenolat yang berasal dari kelompok flavonoid maupun dari kelompok polifenol berperan sebagai antioksidan. Akan tetapi aktivitas antioksidannya sangat ditentukan oleh jenis senyawa fenolat. Senyawa fenol merupakan senyawa yang banyak terdapat pada semua jenis tanaman (Anwariyah, 2011). Selanjutnya dari hasil penelitian terhadap tanaman Cymodocea rotundata diduga senyawa fenol berpengaruh terhadap kandungan antioksidan karena Meenakshi $d k k$ (2009) dan Lim $d k k$ (2002) dalam Anwariyah (2011) menyatakan bahwa ada hubungan antara total fenol dan aktivitas antioksidan dimana jika suatu bahan mememiliki konsentrasi senyawa fenol yang tinggi maka aktivitas antioksidan dalam bahan tersebut juga tinggi.

Hasil ekstraksi dari 3 varietas ubi banggai menunjukkan ketiga varietas mengandung senyawa fenolat dengan kandungan tertinggi pada ubi banggai putih kemudian diikuti oleh ubi banggai ungu dan ubi banggai kuning. Ubi banggai putih diduga mengandung senyawa fenol alami yang telah diketahui memiliki lebih dari seribu struktur dengan flavonoid merupakan golongan terbesar. Dan sebagian besar senyawa flavonoid ditemukan dalam bentuk glikosida, yaitu kombinasi antara suatu gula dan alkohol yang saling berikatan melalui ikatan glikosida (Suradikusumah, 1989 dalam Anwariyah 2011)

Uji aktivitas ekstrak ubi banggai yang kadar fenolatnya tertinggi dilakukan yang selanjutnya dibandingkan dengan aktivitas antioksidan sintetik yang umum digunakan dalam pengolahan pangan, yakni Butylated Hidroksi Toluen (BHT) 200 ppm. Hasil yang diperoleh menunjukkan aktivitas antioksidan tertinggi $(75,75 \%)$ ditemukan pada BHT, dan aktivitas antioksidan terrendah (37,19\%) terdapat pada ubi banggai kuning (Gambar 4.5 Tabel Lampiran 11).

Aktivitas antioksidan sejalan dengan kandungan fenolat, sebab aktivitas antioksidan tertinggi $(74,87 \%)$ ditemukan pada ubi banggai putih, diikuti dengan ubi banggai ungu $(61,17 \%)$ dan terakhir ubi banggai kuning dengan aktivitas antioksidan sebesar 37,19\% (Gambar 4.5). Menurut Andayani $d k k$ (2008) dalam Anwariyah (2011), senyawa fenol yang memiliki aktivitas antioksidan biasanya memiliki gugus - OH dan -OR seperti flavonoid dan asam fenolat. Hal yang sama dinyatakan oleh Oktaviana (2010) dalam Anwariyah (2011) bahwa senyawa fenol bisa berfungsi sebagai antioksidan karena kemampuannya meniadakan radikal - radikal bebas dan radikal peroksida sehingga efektif menghambat oksida lipida. Disamping itu diduga ada senyawa fenolat lain yang terdapat dalam ubi banggai putih sehingga dapat meningkatkan aktivitas antioksidannya (Arinanti $d k k, 2002$ ). 
Ubi banggai ungu dan ubi banggai kuning memiliki aktivitas antioksidan yang relatif lebih rendah karena kandungan fenolat kedua varietas ubi tersebut juga relatif lebih rendah dibanding ubi banggai putih. Dan diduga pula bahwa ekstraksi senyawa fenolik dengan pengekstrak etanol berpengaruh pada aktivitas antioksidannya karena penggunaan pengekstrak yang tidak sesuai dengan sifat bahan yang diekstrak dapat mempengaruhi pengukuran jumlah senyawa antioksidan dan aktivitasnya (Arinanti $d k k, 2002$ )

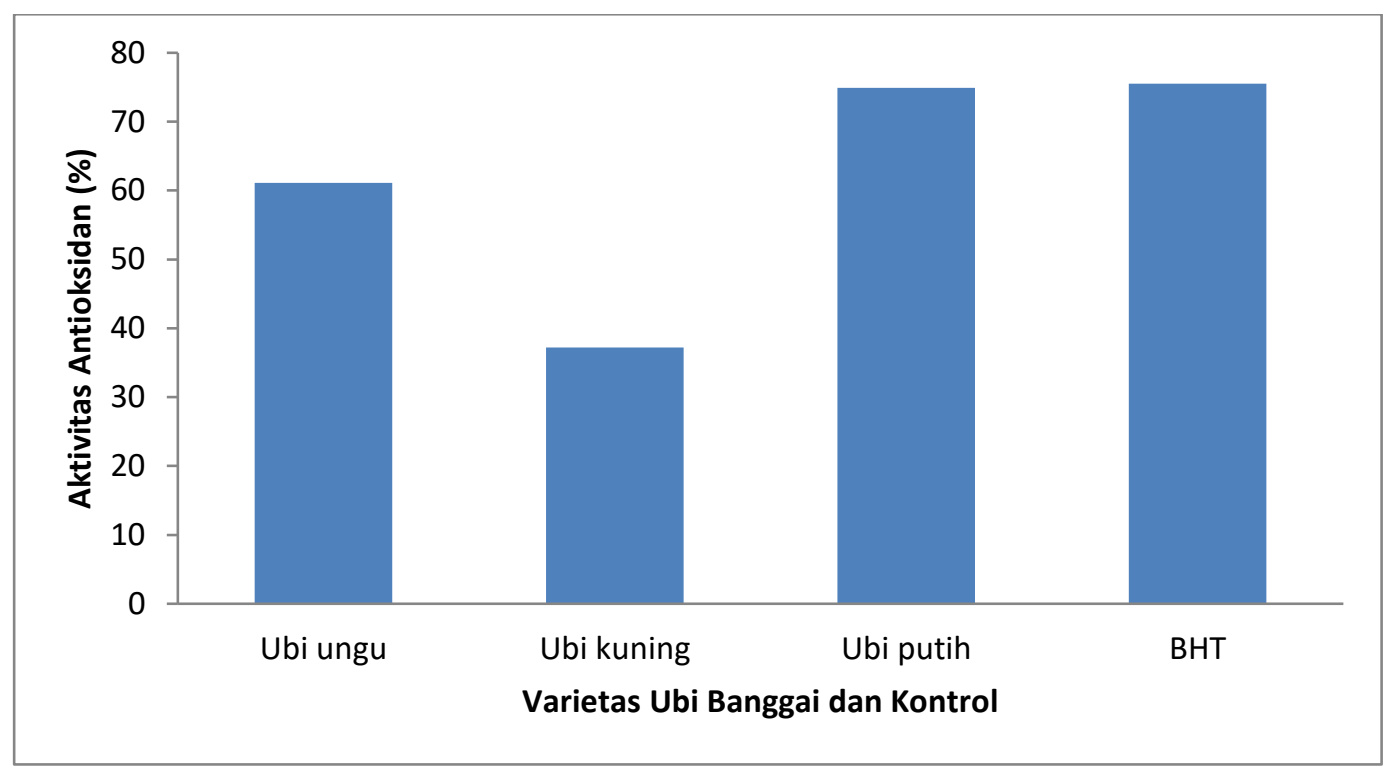

Gambar 4.5 Histogram Aktivitas Antioksidan Ubi Banggai dan BHT

Varietas ubi banggai berpengaruh nyata terhadap aktivitas antioksidan (Tabel Lampiran 14). Hasil analisis lanjut dengan Uji BNJ taraf 5\% menunjukkan aktivitas antioksidan berbeda antar varietas ubi banggai (Tabel Lampiran 15). Hal ini memberikan indikasi kadar fenolat ubi banggai sejalan dengan aktivitas antioksidannya.

Aktivitas antioksidan ekstrak ubi banggai putih tidak berbeda dengan aktivitas antioksidan BHT (Tabel Lampiran 15). Dengan demikian, ubi banggai putih termasuk penghasil senyawa antioksidan alami yang relatif tinggi. Senyawa antioksidan alami pada tumbuhan umumnya adalah senyawa fenolik yang dapat berupa golongan flavonoid, turunan asam sinamat, kumarin, tokoferol, dan asam-asam organik polifungsional. Senyawa antioksidan alami polifenol dan flavonoid yang bersifat relatif polar dan berperan aktif sebagai antioksidan. Sebagai antioksidan, flavonoid memiliki kemampuan sebagai penangkap radikal bebas dan pengkompleks ion logam (Robinson, 1991 dalam Tensiska $d k k, 2003$ ).

Prosant $d k k, 2010$ menyatakan aktivitas antioksidan ubi jalar ditentukan oleh kandungan flavonoid, sedangkan flavonoid termasuk senyawa fenolat. Hal yang sama dikemukakan oleh. Zhang (2007), Everette (2012) dan Ghasemzadeh (2012) yang 
menyatakan bahwa kadar fenolat total hasil ekstraksi tanaman ubi jalar berkorelasi tinggi dengan aktivitas antioksidan. Sebagai perbandingan dengan hasil penelitian Teow $d k k$ (2006) menunjukkan bahwa aktivitas antioksidan bervariasi antara varietas ubi jalar dan intensitas warna ubi cenderung sejalan dengan aktivitas antioksidannya.

\section{KESIMPULAN DAN SARAN}

\section{Kesimpulan}

1. Rasio etanol terhadap tepung ubi banggai dari berbagai varietas yang menghasilkan kadar fenolat tertinggi terdapat pada rasio $15: 1(\mathrm{v} / \mathrm{b})$;

2. waktu ekstraksi tepung ubi banggai dari berbagai varietas yang menghasilkan kadar fenolat tertinggi terdapat pada waktu ekstraksi 2 jam;

3. ubi banggai puth mengandung fenolat tertinggi $(2,63 \%)$ diikuti oleh ubi banggai ungu $(2,44 \%)$ dan ubi banggai kuning $(1,90 \%)$;

4. ubi banggai putih memiliki aktivitas antioksidan tertinggi $(74,87 \%)$ diikuti oleh ubi banggai ungu $(61,17 \%)$ dan ubi banggai kuning $(37,19 \%)$.

\section{Saran}

Berdasarkan hasil penelitian disarankan :

1. Untuk dilakukan penelitian lanjut tentang isolasi dan identifikasi senyawa fenolat pada ketiga jenis ubi banggai;

2. untuk dilakukan penelitian lanjut tentang kandungan fenolat dari berbagai kepekatan warna ubi banggai;

3. untuk dilakukan upaya pengembangan ubi banggai sebagai bahan pangan alternatif sumber antioksidan;

4. untuk dilakukan upaya pengembangan bahan pangan berbasis umbian mendukung program ketahanan pangan nasional.

\section{DAFTAR PUSTAKA}

Andayani,R.,Y. Lisawati dan Maimunah, 2008. Penentuan aktivitas antioksidan, kadar fenolat total dan likopen pada buah tomat ( Solanum Lycopersicum L.), Jurnal Sains dan Teknologi Farmasi, Vol 13 (1)

Anwariyah, S, 2011. Kandungan Fenol, Komponen Fitokimia dan aktivitas antioksidan Lamun Cymodocea rotundata. Departemen teknologi Hasil Perairan Fakultas Perikanan dan Ilmu Kelautan. Institut Pertanian Bogor

Agwunobi, L.N., 1999. Dioscorea alata ( water yam) as a replacement for maizei diets laying hens. Tropical animal Health and production; Dec 1999; 31(6), 391- 396; ProQuest Agriculture Journals 
Arinanti M, Marsono Y, Noor Z, 2002. Aktivitas Antioksidan pada Berbagai Jenis Kacang. Program Studi Ilmu dan Teknologi Pangan Sekolah Pascasarjana Universitas Gadjah Mada

Arnau G, Nemorin A, Maledon E and Abraham K, 2009. Revision of Ploidy Status of Dioscorea alata L.

( Dioscoreaceae ) by cytogenetic and microsatellite segregation analysis. Theor Appl Genet (2009)118 : 1239-1249

Barus, Pina, 2009. Pemanfaatan Bahan Pengawet dan Antioksidan Alami pada Industri Bahan Makanan. Pidato pengukuhan jabatan Guru Besar Tetap dalam bidang Ilmu Kimia Analitik pada Fakultas MIPA Universitas Sumatera Utara, Medan

Boesalem M, Viader V, Mariac C, Gomez R-M, Hochu I, Santoni S, and David J, 2010. Evidence of diploidy in the wild Amerindian yam, a putative progenitor of the endangered species Dioscorea trifida (Dioscoreaceae). Publised on the NRC Research Press Web site at genome.nrc.ca on 24 April 2010

Champagne, 2011. Biological Pigments: Research Result from Chatolic University Update Knowledge of Biological Pigments. The Journal of Food Composition and Anthocyanins and Other Phenolic Compound among Tropical Root Crops from Vanuatu, South Pasific. Journal of Food Composition Analisis, 2011: 24(3) : 315-325

Chan EWC; Lim YY, 2006. Antioxidant Activity of Thunbergia Laurifolia Tea. Journal of Tropical Forest Science; 20,2;Proquest Agriculture Journals pg. 130

Chung, 2008. Food Science; Research in the area of Food Science Reported from Asian University. Internasional Jurnal of Food Science and Technology, 2008: 43(5):859864

Delahaye, PD and Techeira N, 2009. Chemical and Functional Properties of native and Modified Yam (Dioscorea alata) Starch. Biologa, Universidad Central de Venezuale (UCV)

Duvivier P, Hsieh PC, Lai PY, Charle AL, 2010. Retention of Phenolics, carotenoids, and Antioxidant Activity in the Taiwanese sweet potato (Ipomoea batatas L.) CV tainong 66 subjected to different drying conditions. African Journal of Food Agriculture, Nutrition and Development. Vol. 10, No. 11

Eni AO, Hughes J.d'A. Asiedu R, 2008. Sequence diversity among badnavirus isolates infecting yam ( Dioscorea spp. ) in Ghana, Togo, Benin and Nigeria. Original Article. Arch Virol (2008) 153:2263-2272

Everette JD and Islam S, 2012. Effect of Extraction Produsers, Genotypes and screening Methods to Measure the Antioksidan Activity Potential and Phenolic content of Orange-fleshed sweet potato (Ipomoea batatas L.). Journal of Agricultural and Food Chemistry 54(23), pp 8733-8737

Fitrya, Anwar L, Novitasari E, 2010. Isolasi Senyawa Fenolat dari fraksi Etil Asetat Kulit Batang Tumbuhan Gandaria. Jurnal Penelitian Sains Volume 13 Nomor 1(c) Jurusan kimia FMIPA Universitas Sriwijaya, Sumatera Selatan.

Ghasemzadeh A, Omidvar V, Jaafar HZE, 2012. Polyphenolic content and Their Antioxidant Activity in Leaf Extract of sweet Potato (Ipomoea batatas L.) Journal of Medicinal Plant Research Vol. 6(15), pp. 2971-2976. Departement of Agronomy, Science and Research Barnel Islamic Azad University, Teheran Iran.

Hartatik E, 2007. Pengaruh Lama Fermentasi dan Dosis Ragi terhadap Kadar Alkohol Hasil Fermentasi Sari Umbi Uwi ( Dioscorea alata L ). Fakultas Keguruan dan Ilmu Pendidikan Universitas Muhammadiyah Surakarta

Ibrahim, S. 1997. Penggunaan Statistika dalam Validasi Metode Analitik dan Penerapannya dalam Prosiding Temu Ilmiah Nasional Bidang Farmasi. ITB. Bandung. 
Ilham, AM, Vimala S, Rashih AA, Rohana S, Jamaluddin M and Juliza M, 2008. Antioxidant and antityrosine Properties of Malaysian Bamboo Leaf Extracts. Journal of Tropical Forest Science 20(2):123-131

Jaleel CA, Manivanan P, Gomathinayagam M, 2007. Responses of Antioxidant Potential in Dioscorea rotundata. Poir. Following Paclobutrazol Drenching. CR Biol. 2007 Nov;330(11):798-805. Stress Physiology Lab. Departement of Botany, Annamalai University, Annamalainagar 608 002, Tamil Nadu, India

Karakaya, Sibel, 2004. Bioavailability of Phenolic Compound.Critical Review in Food Science and Nutrition;2004:44,6 ProQuest Agriculture Journal pg 453

$\mathrm{Ke} \mathrm{Hu}$ and Yao Xinsheng, 2002. The cytotoxicity of Protoneodioscin (NSC-698789), a furostanol saponin from rhizomes of Dioscorea collettii var. Hypoglauca, against human cancer cells in vitro. Phytomedicine 9:560-565, 2002 melalui http://www.urbanfischer.de/journals/phytomed tanggal 18 November 2011 jam 13.55

Koida M, 2005. Analisis produksi dan pendapatan usaha tani Ubi Banggaidi desa Bakalan Kecamatan Tinangkung Kabupaten Banggai Kepulauan. Skripsi program studi Agribisnis Fakultas Pertanian Universitas Tadulako Palu

Leman, I. 2009. Analisis Kadar Fenol, Karbonil, dan Asam serta Senyawa Volatil Asap Cair dari Sabut Kelapa. Skripsi. Program Studi Pendidikan Kimia. FKIP. Universitas Tadulako. Palu.

Limbongan, J dan Alberth A, 2007. Ketersediaan teknologi dan Potensi Pengembangan Ubi Jalar (Ipomoea batatas L.) di Papua. Journal Litbang Pertanian, 26(4), BPTP Papua Jayapura.

Mappiratu. 2005. Lipida Pangan (Kimia, Biologi dan Bioteknologi). Universitas Tadulako, Palu.

Miller, J.C, and J.N. Miller. 1993. Statistics for Analytical Chemistry, $3^{\text {rd }}$ ed. Ellis Horwood PTR Prentice Hall. New York.

Montilla, EC, Silke H, Peter W, 2011. Antocianins in Purple Sweet Potato (Ipomoea batatas L.) Varieties. Institute of Food Chemistry, Technische Braunschweig, Schleinizst, Germany.

Mun'im, A. Azizahwati dan Trastiana. 2008. Aktivitas Antioksidan Cendawan Suku Pleurotaceae dan Polyporaceae dari Hutan UI, Jurnal Ilmiah Farmasi Vol 5(1). Departemen Farmasi FMIPA UI, Depok.

Narina SS, Buyyarapu R, Kottapalli KR, Sartie AM, Ali MI, Robert A, Hodeba MJD, Sayre BL, Scheffler BE, 2011. Generation and analysis of expressed sequence tags (ESTs) for marker development in yam (Dioscorea alata L.). BMC Genomics 2011, 12:100 melalui http://www.biomedcentral.com/1471-2164/12/100 tanggal 18 November 2011

Obidiegwu J, Loureiro J, Obong EE, Rodriguez E, Kolesnikova-A M, Santos C, Muoneke C and Asiedu R, 2009. Ploidy level studies on the Dioscorea cayenensis/Dioscorea rotundata complex core set. Euphytica (2009)169:319-326 published online 21 mey 2009

Oh, Phil-Sun and Lim Kye-Taek, 2008. Antioxidant activity of Dioscorea batatas Decne glycoprotein. Eur Food Res Technol (2008) 226:507-515

Omoruyi, FO and Dilworth L, 2007. Anti-nutritional factors, Zinc, iron and calcium in some Caribbean tuber crops and the effect of boiling or roasting. Nutrition \& Food Science Vol.37 No.1 2007 pp $8-15$

Orak, HH, 2006. Total antioxidant activities, phenolic, antocyanins polyphenolixidae activitiesin read grape varieties. Electronic Journal of Polish Agricultural University Food Science and Technology. Vol 9 Issn- 188 htm. 
Osunde, ZD., 2008.Minimizing Postharvest Losses in Yam (Dioscorea spp):Treatment and Techniques.Departement of Agricultural and Bioresources Engineering, Federal University of Technology, Minna, Nigeria

Ovono, PO, Kevers C and Dommes J, 2009. Tuber formation and Growth of Dioscorea cayenensis-D.rotundata complex: interaction between exogenous and endogenous jasmonic acid and polyamines. Plant Growth Regul (2010) 60:247-253

Palupi NS, Zakaria FR, Prangdimurti E, 2007. Pengaruh Pengolahan Terhadap Nilai Gizi Pangan. Departemen Ilmu dan Teknologi Pangan-Fateta-IPB Bogor.

Pambayun, R., Gardjito M, Sudarmanji S dan Kuswanto KR, 2007. Kandungan Fenol dan sifat antibakteri dari berbagai jenis ekstrak produk gambir (Uncaria gambir Roxb). Majalah Farmasi Indonesia, vol 8 (3)

Pujimulyani, D., A. Wazyka., S. Anggrahini dan U. Santoso. 2006. Pengaruh Metode Ekstraki Terhadap Aktivitas Antioksidan Ekstrak Kunir Putih (Curcuma mangga Val). Jurnal Agritech. 26(1) : 34-38.

Ramadhanil dan Gradstein SR, 2003. Herbarium Celebense (CEB) dan peranannya dalam Menunjang Penelitian Taksonomi Tumbuhan di Sulawesi. Biodiversitas Volume 5, nomor 1 hal. 36-41

Rahmatu, R.Dg, Ramadhanil, dan Sangaji MN, 2001. Inventarisasi dan Identifikasi Tanaman Ubi Banggai di Kepulauan Banggai Sulawesi Tengah. Proyek Penelitian ARMP-II, Kerjasama Universitas Tadulako dengan Balai Penelitian Tanaman Pangan, Palu:Universitas Tadulako

Rahmatu, R.Dg, Ramadhanil, Muhardi, Sangaji MN dam Alam N, 2002. Pengelolaan Pasca Panen Ubi Banggai, kajian Karakteristik Tepung Ubi Banggai. Proyek Penelitian ARMP-II, Kerjasama Universitas Tadulako dengan Balai Penelitian Tanaman Pangan, Palu:Universitas Tadulako

Retnati, 2009. Pengaruh Penambahan Ekstrak berbagai Jenis Ubi Jalar (Ipomoea batatas L) Terhadap Jumlah Sel dan Aktivitas Antioksidan Yoghurt. Skripsi Fakultas Pertanian Universitas Sebelas Maret Surakarta

Robinson T, 1991. Kandungan Organik Tumbuhan Tinggi. ITB Bandung

Sabili H, 2007. Antioksidan Alami Sehat Alami. Melalui http:www.sinarmasgroup.com tanggal $30-09-2011$

Sastrahidayat, IR dan Soemarno, DS, 1986. Budidaya Berbagai Jenis Tanaman Tropika. Fakultas Pertanian Universitas Brawijaya Malang bekerjasama dengan Usaha Nasional Surabaya.

Sarastani D, Soewarno T. Soekanto, Muchtadi D , Fardiaz D dan Apriyantono A, 2002. Aktifitas antioksidan Ekstrak dan Fraksi Ekstrak Biji Atung (Parinarium glaberrimum Hassk.). J. Teknol dan Industri Pangan, XII(2): 149-156

Septiana AT, Muchtadi D dan Zakaria FR, 2002. Aktivitas Antioksidan Dikhlorometana dan Air Jahe (Zingiber officinale Roscoe) pada asam linoleat.J. Teknologi dan Industri Pangan,XIII(2):105-110

Siswono, H, 2008. Isolasi dan Identifikasi Komponen Kimia Ekstrak Etanol 95\% dari Apium graveolens Linn.var.secalium Alef. Perpustakaan digital ITB, Bandung.

Steed, LE and Truong, VD, 2008. Antocianin content, Antioksidant Activity, and Selected Physical Properties of Flowable Purple Fleshed Sweet Potato Purees.Journal of Food Science, Vol. 73, Nr.5 $215-221$

Syarifah, Z. 2006. Potensi Imunomodulator Bubuk Kakao Bebas Lemak sebagai Produk Substandar Secara In Vitro Pada Sel Limfosit Manusia. Fakultas Teknologi Pertanian. IPB. Bogor. 
Tambunan, 2010. Isolasi senyawa flavonoida dari bunga tumbuhan Rosella (Hibiscus Sabdariffa L). Fakultas Matematika dan Ilmu Pengetahuan Alam Sumatra Utara Medan.

Tamiru M, Becker HC and Maass BL, 2007. Genetic Diversity in Yam Germplasm from Ethiopia and Their Relatedness to the Main Cultivated Dioscorea Species Assessed by AFLP Markers. Crop Science; Jul/Aug 2007;4,4;ProQuest Agriculture Journals

Teow, CC, Tuong Van-Den, McFeeters RF, Thompson RL, Pecota KV, Yencho, GC, 2006. Antioxidant activities, Phenolic and $\beta$-caroten content of sweet potato genotypes with varying flesh colours. Food chemistry 103 (2007) 829 - 838

Tensiska, Wijaya CH dan Andarwulan N, 2003. Aktivitas Antioksidan Ekstrak Buah Andaliman ( Zanthoxylum acanthopodium DC) Dalam Beberapa Sistem Pangan dan Kestabilan Aktivitasnya Terhadap Kondisi Suhu dan pH. J. Teknologi dan Industri Pangan, Vol. XIV No. 1 hal. 29-38

Wahibah,NN, 2002. Daya silang Ubi Jalar Berdaging Umbi Jingga dengan Ipomoea trifida Diploid dan Hubungan Genetiknya berdasarkan RAPD. Jurnal Natur Indonesia 5(1): 1-8, Universitas Riau

Wijono, SH, 2004. Isolasi dan Identifikasi Asam Fenolat pada Daun Katu (Sauropus androgynus (L.) Merr.). Makara, Kesehatan, Vol. 8, No.1, Juni 2004: 32 - 36

Wikipedia, 2005. Yam (vegetable ). Wikipedia, the free encyclopedia. Yam wikipedia.htm

Wilson JE, 1989. Rapid Multiplication of Yams ( Dioscorea spp ). IRETA Publication No. 3/88 USP Alafua Campus P.O Private Bag Apia, Western Samoa

Wong, SK, Lim YY and Chan EWC, 2009. Antioxidant Properties of Hibiscus: Species Variation, Altitudinal Change, Coastal Influence and Floral Colour Change.Journal of Tropical Forest Science 21 (4):307-315

Wulandari, SA., 2011. Ekstraksi dan Analisis Kandungan Fenolat Ekstrak Etanol Kulit Ari Biji Kakao (Theobroma cacao, L.) Skripsi progam studi kimia Fakultas Matematika dan Ilmu Pengetahuan Alam Universitas Tadulako Palu

Wulandari, DR, 2009. Pengembangan Dioscorea spp Sebagai Bahan Pangan Fungsional Bebas Gluten dan Konversinya Secara In Vitro. Laporan Pusat Penelitian Bioteknologi LIPI. Jakarta

Yuniar, DP, 2010. Karakteristik Beberapa Umbi Uwi ( Dioscorea spp) dan Kajian Potensi Kadar Inulinnya. Skripsi program studi Teknologi Pangan Fakultas Teknologi Industri Universitas Pembangunan Nasional Veteran Surabaya.

Zhang Y, 2007. Antioxidant Activity of Polyphenolic Extract from Ipomoea batatas L. Departement of Bioengineering and Food Processing Shanghai Institute ofTechnology, Shanghai. 
